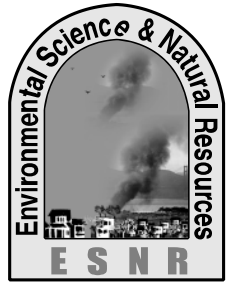

\title{
Seed Borne Fungal Diseases of Fruits in Mymensingh District
}

\author{
A. Q. M. B. Rashid, M. B. Meah and A. Sultana*
}

Department of Plant Pathology, Bangladesh Agricultural University, Mymensingh-2202

*Corresponding author: af.sultana87@gmail.com

\begin{abstract}
An experiment was conducted to evaluate the major seed borne fungal diseases of fruits in Mymensingh. Being perishable crop the fruits were found easily prone to the attack of various disease causing organisms at almost all sphere of their production practices from orchard to the storage, transit and consumption. Fruit rot (Botryodiplodia theobromae) and anthracnose (Colletotrichum gloesporioides) were found as the most common and serious diseases in many fruits such as mango, guava, banana, papaya, pineapple etc. Prevalence of the diseases, losses incurred and probable control measures have been suggested in most of the cases.
\end{abstract}

Key words: Fungal diseases, Perishable crops, Production, Quality

\section{Introduction}

Bangladesh is naturally fortuned and blessed with the production of various seasonal fruit crops all the year round. But the qualitative and quantitative production is much lower than that of the corresponding world figures due to poor age-old production technology as well as management practices. Fruits are mainly annual and perennial crops. They are very sensitive and highly perishable in nature so that they become easily prone to the attack of various disease causing organisms at any spare of their production practices from the orchard to the storage, transit and consumption. Fruits are usually vegetative propagated through sucker, budding, cutting, grafting etc. which may play a vital role in the transmission of various diseases. In case of perennial fruits such as mango, jackfruit, litchi etc. the pathogens can easily survive on the different plant parts from where the primary inocula may cause infection to the next bearing. In this way the fruit crops may suffer from such various consistent diseases. But there is no reported much organized works on the diseases. Therefore, the present work was done to evaluate the fungal diseases of fruits sporadically prevalent at Mymensingh district.

\section{Major seed borne fungal diseases of fruits}

Table 1.The most important fungal diseases of different fruit crops of Mymensingh

\begin{tabular}{|l|l|c|l|}
\hline No. & \multicolumn{1}{|c|}{ Disease } & Host & \multicolumn{1}{c|}{ Pathogen } \\
\hline 1. & Stem end rot & Mango & Botryodiplodia theobromae \\
\hline 2. & Anthracnose & Mango & Colletotrichum gloesporioides \\
\hline 3. & Malformation & Mango & Fusarium moniliforme \\
\hline 4. & Twig and fruit rot & Mango & Phoma sp. \\
\hline 5. & Anthracnose & Guava & Colletotrichum gloesporioides \\
\hline 6. & Wilt & Jackfruit & Fusarium oxysporum \\
\hline 7. & Fruit rot & Banana & Rhizopus artocarpi \\
\hline 8. & Anthracnose & Banana & Botryodiplodia theobromae \\
\hline 9. & Fruit rot/stem end rot & Banana & Cercospora musae \\
\hline 10. & Sigatoka & Pineapple & Botryodiplodia theobromae \\
\hline 11. & Fruit rot & Pineapple & Sclerotium rolfsii \\
\hline 12. & Soft rot & Papaya & Colletotrichum gloesporioides \\
\hline 13. & Anthracnose & Papaya & Alternaria tenius \\
\hline 14. & Leaf spot & Papaya & Drechslera rostrata \\
\hline 15. & Leaf blight & Papaya & Fusarium sp. \\
\hline 16. & Foot rot & Papaya & Rhizopus stolonifer \\
\hline 17. & Fruit rot & Litchi & Fusarium moniliforme \\
\hline 18. & Fruit crack & Jujube & Oidium sp. \\
\hline 19. & Powdery mildew &
\end{tabular}

\section{Mango}

Mango (Mangifera indica L.) is among the fruit plants rich in vitamin $\mathrm{C}$ that is in most tropical regions of the world and most eaten in the developed countries Diedhiou et al. (2007).
Anthracnose has been reported in many parts of the world where the climate is suitable for mango production to be the most important field and postharvest disease of the crop (Sangeeta and 
Rawal, 2009; Chowdhury et al., 2008). Anthracnose and fruit rot caused by Colletotrichum gloesporoides and Botryodiplodia theobromae are the major seed borne fungal diseases of mango. Anthracnose affects leaves, flowers and fruits and inocula are present year round throughout the canopy. While stem end rot caused by $B$. theobromae is a major post harvest disease of mango. Particularly stem end rot caused by $B$. theobromae is a serious post harvest problem of mango mainly during transportation, storage and marketing under hot $\left(28-30^{\circ} \mathrm{C}\right)$ and humid (8000\%rh) conditions (Quroshi and Meah, 1991). They also reported that, $B$. theobromae can easily survive up to 5-6 months at either the room temperature of $25-32^{\circ} \mathrm{C}$ or at freezing point in the form of mycelium or fruiting body. As the mangoes undergo ripening, glucose along with other sugars (sucrose and fructose) increases and enhances the growth and sporulation of the fungus which results heavy rotting. Almost similar type of post harvest decay occurred in mango by anthracnose and stem end rot. Besides, mango malformation, twig blight and fruit rot have also been reported in mango (Meah and Khan, 1987).

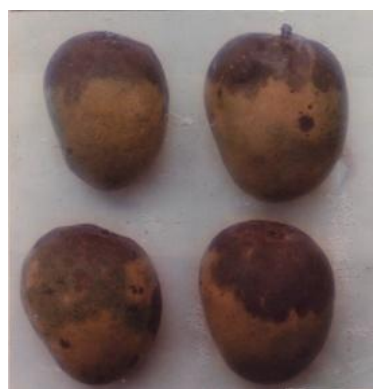

Fig.1. Stem end rot of mango caused by $B$. theobromae

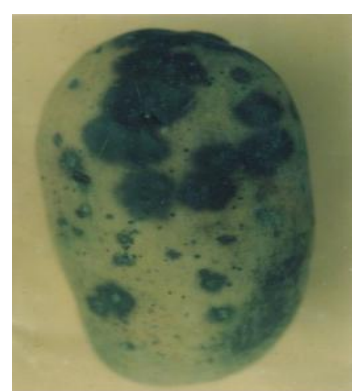

Fig.2. Anthracnose of mango caused by $C$. gloeosporoides
Mature green hard mangoes when dipped for three minutes in heated $50^{\circ} \mathrm{C}$ aqueous solution of mancozeb (3a.iL $\left.{ }^{-1}\right)$ and ioprodione $(0.5$ and $0.75 \mathrm{~g}$ a. $\left.\mathrm{iL}^{-1}\right)$ gave excellent control of stem end rot infections. No sign or symptom developed either in storage or during ripening and after wards (Meah, 2000).

\section{Guava}

Guava is a very common and important fruit crop which suffers from a serious problem of anthracnose disease caused by Colletotrichum gloesporioides occurring every year in different parts of the country (Meah and Khan, 1988). Severely infected guava fruits possess necrosis, loss of the fruit value, become fully unfit for consumption and affect the market price (Delware, 1995). The pear shaped fruits were found less susceptible than the elliptical round fruits (Rahman, 1992). Hossain and Meah (1992) reported that $100 \%$ plants and $90-100 \%$ fruits were severely diseased in three major guava producing area of the country. While Hasna et al. (2000) estimated 30\% fruit weight loss in Kazipeyara. Topsin M was found to reduce the fruit infection and disease severity significantly up to $89.5 \%$ followed by Rovral FLO (87.0\%) over control.

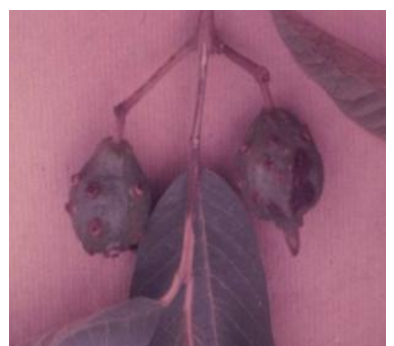

Fig.3. Anthracnose of guava caused by $C$. gloeosporioides

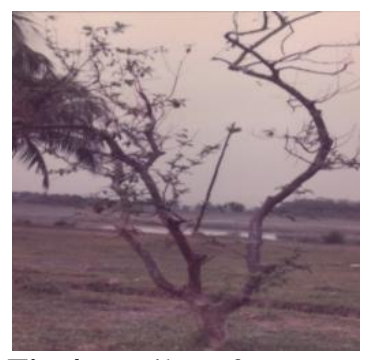

Fig.4. Wilt of guava aused by $F$. oxysporum
Wilt of guava caused by Fusarium oxysporum is another serious problem for guava plantation in the country Hamiduzzaman et al. (1999). Sudden drooping of entire foliage or withering of top twigs followed by side branch wilting is the common symptoms of the disease. Cross section of the affected roots, stems and twigs revealed damage of epidermal cell, discoloration of parenchymatous cells and darkening xylem vessels. Older plants showed more proneness to wilting (Haque, 1996).

\section{Banana}

Banana is one of the most important palatable cosmopolitan fruits grown all year round in almost everywhere in the country. This crop suffers from fungal diseases, among which anthracnose caused by Colletotrichum gloesporioides, fruit rot/stemend rot/ distal end rot caused by Botryodiplodia theobromae and sigatoka caused by Cercospora musae are of economic significance. It may be mentioned here that an extensive work on banana diseases is being carried out at present in the Plant Pathology Department, Bangladesh Agricultural University.

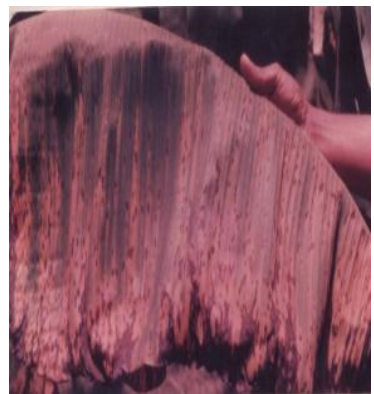

Fig.5. Sigatoka of banana caused by $C$. musae

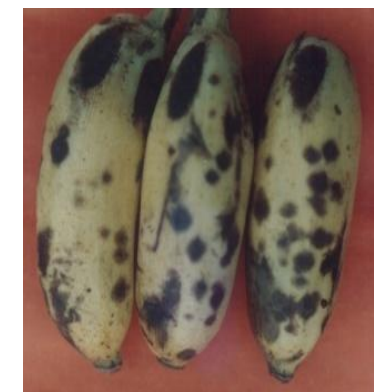

Fig.6. Anthracnose of banana caused by $C$. gloeosporoides

\section{Jackfruit}

Jackfruit is the national fruit of Bangladesh. It suffers from a serious disease namely fruit rot caused by Rhizopus artocarpi. The fruit becomes affected usually at the younger stage. 


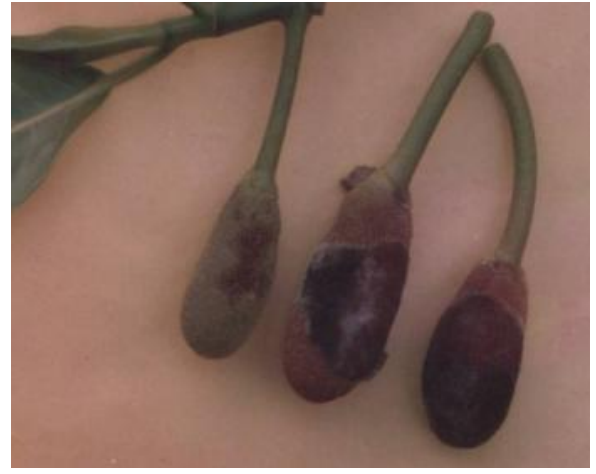

Fig.7. Fruit rot of jackfruit caused by $R$. artocarpi

\section{Papaya}

Papaya is another palatable important fruit crop in Bangladesh. In an investigation by (Alam, 1989) reported four diseases caused by fungi such as leaf spot (Alternaria tenius), leaf blight (Drechslera rostrata), foot rot (Fusarium sp.) and fruit rot (Rhizopus stolonifer). While Meah et al. (1992) reported anthracnose caused by Colletotrichum gloesporoides as a serious disease of papaya in the country. This disease appears in the field condition on mature fruits and manifest proliferated symptoms. Meah et al. (1992) reported control measure of the papaya disease by spraying of iprodione @ 2.0gl ${ }^{-1}(2000 \mathrm{ppm})$ and post harvest dips of mature hard fruits in the mancozeb solution of 50 for 3 minutes to control the disease and maintain the marketability of papaya fruits.

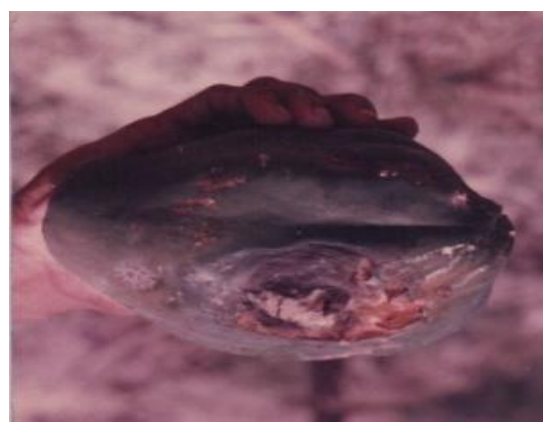

Fig.8. Fruit rot of papaya caused by $R$. stolonifer

\section{Pineapple}

Pineapple is an important seasonal fruit of Bangladesh and has been reported to be affected by at least two fungal diseases such as black fruit rot caused by $B$. theobromae and soft rot caused by

\section{References}

Alam, Z. 1989. Survey of the prevalence of banana, papaya and pineapple. M.S. Thesis, Department of Plant Pathology, BAU, Mymensingh.

Chowdhury, M. N. A.; Rahim, M. A.; Khalequzzaman, K. M.; Alam, M. J. and Humauan, M. R. 2008. Effect of horticultural practices on incidence of anthracnose on yield
Sclerotium rolfsii (Alam, 1989). Black fruit rot diseases manifest the symptoms as the dark brown thee fruit skin numerous black dots. Gradually the whole fruit becomes rotten with blackend flesh and unfit for consumption. While the soft fruit rot occurs as water soaked lesion on the skin. Infected part becomes soft and rots soon. Finger press results to let of ooze. White cottony mycelial growth may be observed on the rotten area.

\section{Litchi}

Litchi is also the popular fruits of Bangladesh. Various diseases on this fruit crops are being studied by (Meah, 2000) who already reported fruit crack of litchi caused by Fusarium moniliforme.

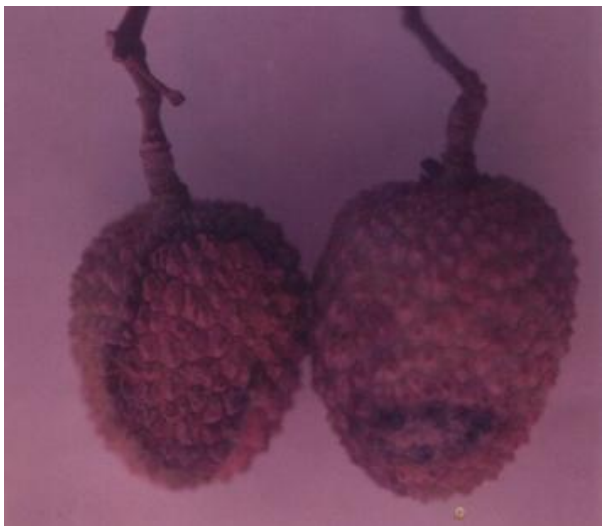

Fig.9. Fruit crack of litchi caused by $F$. moniliforme

\section{Conclusions}

Most of the fruit crops are either annual or perennial and are usually propagated vegetative through sucker, budding, cutting, grafting etc. which might play vital role in the transmission of various diseases. Coincidentally, almost all of the fungal pathogens causing fruit diseases under study are exclusively seedborne in the field crops. However the diseases causing organisms also might remain viable with different parts of the perennials and serve as the source of primary inocula to initiate infection to the next bearing. In this way, the diseases might consistently be transmitted from season to season and crop to crop. The proper management practices are suggested to get rid of the situation.

and quality of mango. Int. Jour. of Sust. Crop Prod., 3: 1-9.

Delware, H. M. 1995. Effect of soil amendment on the prevalence of guava anthracnose and biochemical basis of its severity. MS Thesis, Dept. of Plant Pathology, Bangladesh Agricultural University, Mymensigh.

Diedhiou, P. M.; Mbaye, N.; Drame, A. and Samb, P. I. 2007. Alteration of post harvest diseases 
of mango Mangifera indica through production practices and climatic factors. Afrian Jour. of Biotech., 6: 1087-1094.

Hamiduzzaman, M. M.; Meah, M. B. and Doula, M. A. U. 1999. An integrated approach for guava wilt control. Pakistan Jour. of Sci. Indus. Res., 42(5):244-247.

Hasna, A.K.;Meah, M.B. and Kader, M.A. 2000. Assessment of yield loss in guava owing to fruit anthracnose. Pakistan Jour. of Biol. Sci., 3(8):1234-1236.

Hossain, M. S. and Meah, M. B. 1992. Prevalence and control of guava fruit anthracnose. Tropical Pest Management, 38(2):181-185.

Haque, M. M. 1996. Investigation of wilting in guava. MS Thesis, Dept. of Plant Pathology, Bangladesh Agricultural University, Mymensigh.

Meah, M. B. and Khan, A. A. 1988.Survey of diseases of some important fruits and vegetable crops of Bangladesh.Annual Progress report for 1986-87. Bangladesh Agricultural University, Mymensigh.
Meah, M. B. 2000. Residues of mancozeb and iprodione in mango fruits treated for control of stem end rot. Pakistan Jour. of Agri. Res., 16 (1):35-39.

Meah, M. B. and Khan, A. A. 1987. Investigation of mango diseases. MS Thesis, Dept. of Plant Pathology, Bangladesh Agricultural University, Mymensigh.

Meah, M. B.; Siddique, M. K.; Faruque, A. M. and Siddique, M. A. 1992. Chemical control of papaya anthracnose. Progressive Agriculture, 3:27-32.

Quroshi, S.W. and Meah, M.B. 1991. Post harvest losses in mango owing to stem end rot. International Journal of Tropical Agriculture, 9(2):98-105.

Rahman, M. A. 1992. Reaction of guava varieties to anthracnose. MS Thesis, Bangladesh Agricultural University, Mymensigh.

Sangeetha, C. G. and R. D. Rawal, 2009. Temperature requirement of different isolates of Colletotrichum gloeosporioides isolated from mango. American-Eurasian Journal of Scientific Research, 4: 20-25. 